\title{
Function and biotechnology of extremophilic enzymes in low water activity
}

\author{
Ram Karan ${ }^{1,2}$, Melinda D Capes ${ }^{1,2}$ and Shiladitya DasSarma ${ }^{1,2^{*}}$
}

\begin{abstract}
Enzymes from extremophilic microorganisms usually catalyze chemical reactions in non-standard conditions. Such conditions promote aggregation, precipitation, and denaturation, reducing the activity of most non-extremophilic enzymes, frequently due to the absence of sufficient hydration. Some extremophilic enzymes maintain a tight hydration shell and remain active in solution even when liquid water is limiting, e.g. in the presence of high ionic concentrations, or at cold temperature when water is close to the freezing point. Extremophilic enzymes are able to compete for hydration via alterations especially to their surface through greater surface charges and increased molecular motion. These properties have enabled some extremophilic enzymes to function in the presence of nonaqueous organic solvents, with potential for design of useful catalysts. In this review, we summarize the current state of knowledge of extremophilic enzymes functioning in high salinity and cold temperatures, focusing on their strategy for function at low water activity. We discuss how the understanding of extremophilic enzyme function is leading to the design of a new generation of enzyme catalysts and their applications to biotechnology.
\end{abstract}

Keywords: Extremophile, Extremozymes, Protein stability, Halophiles, Psychrophile, Cold activity, Organic solvent, Low temperature, High salinity, Biofuel, Bioenergy

\section{Introduction}

Enzymes are nature's biocatalysts endowed with high catalytic power, remarkable substrate specificity, and ability to work under mild reaction conditions. These unique features led to enzyme applications in competitive bioprocesses as one of the foremost areas of biotechnology research. Most enzymes are active within a defined set of standard conditions close to what is considered normal for mesophilic terrestrial organisms. However, much of the biosphere is extreme by comparison (e.g. cold oceans and dry, salty deserts). Not surprisingly, the biosphere contains a very large number of extremophilic microorganisms with enzymes capable of functioning in unusual conditions $[1,2]$.

The discovery of thermostable DNA polymerases and their impact on research, medicine, and industry has underscored the potential benefits of enzymes from extreme environments [3]. Since that time, the biotechnological and industrial demand for stable enzymes

\footnotetext{
* Correspondence: sdassarma@som.umaryland.edu

'Department of Microbiology and Immunology, University of Maryland

School of Medicine, Baltimore, MD, USA

Full list of author information is available at the end of the article
}

functioning in harsh operational conditions has surged. A great deal of current effort is aimed at screening for new sources of novel enzymes capable of functioning in extreme conditions. The parallel development of sophisticated molecular biology tools has also enabled engineering of enzymes with novel properties using techniques such as site-directed mutagenesis, gene shuffling, directed evolution, chemical modifications and immobilization [4-6].

Microorganisms which grow in extreme conditions have been an important source of stable and valuable enzymes $[1,7,8]$. Their enzymes, sometimes called "extremozymes", perform the same enzymatic functions as their non-extreme counterparts, but they can catalyze such reactions in conditions which inhibit or denature the less extreme forms. Interestingly, some of the enzymes derived from extremophiles display polyextremophilicity, i.e. stability and activity in more than one extreme condition, including high salt, alkaline $\mathrm{pH}$, low temperature, and non-aqueous medium [2,9-11]. A basic understanding of the stability and function of extremozymes under extreme conditions is important for innovations in biotechnology. 
One of the underlying reasons for limited enzyme activity in extreme conditions is their effects on water structure and dynamics. When water activity is perturbed by extreme temperatures, high salinity, or other extreme conditions, normally structured liquid water may become limiting to enzymes, with deleterious consequences to enzyme structure and/or function. For example, at high salinity, water is sequestered in hydrated ionic structures, limiting the availability of free water molecules for protein hydration [12,13]. An analogous effect is felt by enzymes in cold temperatures due to the freezing of water molecules, forming structured ice-like lattices that are less available to interact with proteins [14]. Therefore, improved hydration characteristics in some extremozymes are critical for their function in their natural conditions. An interesting and potentially useful consequence of the hydration properties of such enzymes may be in extending their range of function to non-aqueous environments [5]. Enzymes capable of functioning in the presence of organic solvents may permit their use in some specialized applications, such as for catalysis of reactions using novel substrates. As a result, a better understanding of molecular mechanisms used by such extremozymes for improved solubility and hydration is of substantial biotechnological interest.

\section{Salt adapted enzymes}

Water molecules are known to play a critical role in biological functions of proteins by binding to the surface and incorporating into the interior of protein molecules [15-18]. Water has a tendency to form ordered cages around hydrophobic groups on the protein surface [19]. Salt ions are known to disrupt the local water structure, diminishing the number of intermolecular hydrogen bonds [20-22]. High salt concentrations critically affect the solubility, binding, stability, and crystallization of proteins [23]. The interactions between proteins and protein subunits in solution are also altered by salts. The electrostatic interactions between charged amino acids are also perturbed with significant consequences for protein structure and function [24]. The effects depend on the chemical nature of the salts, generally following the position of ions in the Hofmeister series [25,26].

Water is necessary for native structure, proper function, and to prevent aggregation of proteins. As salt ions inside the cell increases, water is removed from hydrophobic regions of protein surfaces, until proteins are no longer sufficiently hydrated $[17,18,27]$ (Figure 1 ). Nonhalophilic proteins are generally less able to compete with salts and lose their structure and activity at relatively lower ionic concentration. However, halophilic proteins are able to successfully compete with salt ions for hydration and maintain their functional

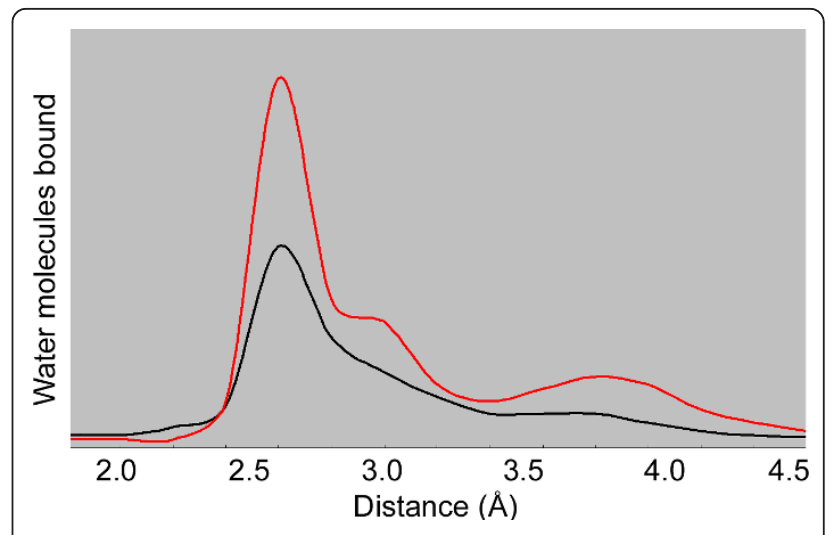

Figure 1 Distribution of the water molecules near the protein surface predicted from high resolution structures (adapted from ref. 30). The relative number of water molecules versus distance is plotted for a halophilic glucose dehydrogenase enzyme active at low water activity (red) [30] and for non-halophilic enzymes (black). Multiple hydration layers may surround extremophilic proteins as a result of their ability to bind more tightly to water than non-extremophilic proteins.

conformation in the presence of high ionic concentration [28-30] (Table 1). This is especially true for proteins from halophilic microorganisms which use the salt-in mechanism for osmotic stabilization (e.g. halophilic archaea and some halophilic bacteria) [8]. Such halophilic proteins have evolved a specific set of molecular features that help them to compete with ions for water and maintain a stable hydration shell. In fact, in comparison to non-halophilic enzymes, halophilic enzymes are found to have multilayered hydration shells that are of considerably greater size and order (Figure 1).

In order to enhance activity in high salt concentrations, an increase in the number of charged amino acids, especially acidic residues at the protein surface, is observed in halophilic proteins [31-35] (Figure 2). Bioinformatic studies of the extreme halophile Halobacterium sp. NRC-1 and other species have shown that an increase in the number of acidic (glutamic acid, and to a lesser extent, aspartic acid) over basic residues is a general property of proteins predicted from the genomes of halophilic microorganisms [13,27] (Figure 2). Glutamate residues have superior water binding capacity over all other amino acids and are generally found in excess on the surface of halophilic proteins $[15,16,28,30]$. Acidic amino acids can constitute a high fraction of an individual protein, with up to $20-23 \%$ having been reported $[36,37]$. The negatively charged amino acids in halophilic proteins bind hydrated cations and help maintain a surface hydration layer, reducing their surface hydrophobicity, and contributing to mutual electrostatic repulsion $[29,35,38]$. These properties prevent aggregation at high salt concentrations [39]. 


\begin{tabular}{|c|c|c|c|}
\hline Name & Organism(s) & Method(s) & $\begin{array}{l}\text { Reference } \\
\text { (s) }\end{array}$ \\
\hline \multicolumn{4}{|l|}{ Salt adapted } \\
\hline$\alpha$-amylase & Halothermothrix sp. & $\begin{array}{l}\text { CD spectroscopy, sedimentation velocity, crystal } \\
\text { structure }\end{array}$ & [59] \\
\hline$\alpha$-amylase & Pseudoalteromonas sp. & CD and fluorescence spectroscopy & [53] \\
\hline Carbonic anhydrase & Dunaliella sp. & Crystal structure & [125] \\
\hline $\begin{array}{l}\text { Cysteinyl tRNA } \\
\text { synthetase }\end{array}$ & Halobacterium sp. & Mutagenesis & [126] \\
\hline $\begin{array}{l}\text { Dihydrofolate } \\
\text { reductase }\end{array}$ & Halobacterium sp. & Homology modeling & [127] \\
\hline Dihydrofolate reductase & Haloferax sp. & Crystal structure & [41] \\
\hline Dihydrofolate reductase & $\begin{array}{l}\text { Haloarcula sp., Halobacterium sp., Haloquadratum sp., } \\
\text { Natrosomonas sp. }\end{array}$ & Homology modeling & {$[38]$} \\
\hline $\begin{array}{l}\text { Dihydrolipoamide } \\
\text { dehydrogenase }\end{array}$ & Haloferax sp. & Homology modeling, site-directed mutagenesis & {$[50]$} \\
\hline DNA ligase & Haloferax sp. & Mutagenesis & [128] \\
\hline DNA ligase & Haloferax sp. & $\begin{array}{l}\text { Site-directed mutagenesis, CD, fluorescence and NMR } \\
\text { spectroscopy }\end{array}$ & {$[35]$} \\
\hline DNA ligase & Haloferax sp. & Homology modeling, CD spectroscopy & [26] \\
\hline Esterase & Haloarcula sp. & Homology modeling, CD spectroscopy & [43] \\
\hline Ferredoxin [2Fe-2S] & Haloarcula sp. & Crystal structure & [29] \\
\hline Ferredoxin [2Fe-2S] & Halobacterium sp. & Fluorescence and CD spectroscopy & {$[48,129]$} \\
\hline $\begin{array}{l}\text { Glutamate } \\
\text { dehydrogenase }\end{array}$ & Halobacterium sp. & Homology modeling & [130] \\
\hline Glucose dehydrogenase & Haloferax sp. & Crystal structure & {$[30]$} \\
\hline Glutaminase & Micrococcus sp. & Crystallization and X-ray crystallography & [131] \\
\hline Malate dehydrogenase & Halobacterium sp. & Fluorescence spectroscopy & [132] \\
\hline Malate dehydrogenase & Halobacterium sp. & $\begin{array}{l}\text { Neutron scattering, ultracentrifugation and quasi-elastic } \\
\text { light-scattering }\end{array}$ & {$[46]$} \\
\hline Malate dehydrogenase & Haloarcula sp. & Densitometry and neutron scattering & [133] \\
\hline Malate dehydrogenase & Haloarcula sp. & X-ray crystallography & {$[28]$} \\
\hline Malate dehydrogenase & Haloarcula sp. & Site-directed mutagenesis & [134] \\
\hline Malate dehydrogenase & Haloarcula sp. & Mutagenesis, crystal structure & [135] \\
\hline Malate dehydrogenase & Haloarcula sp. & Crystal structure, neutron scattering & {$[23]$} \\
\hline Malate dehydrogenase & Salinibacter sp. & Analytical centrifugation, CD spectroscopy & [136] \\
\hline Malate dehydrogenase & Haloarcula sp. & Neutron diffraction, CD and neutron spectroscopy & [19] \\
\hline Malate dehydrogenase & Haloarcula sp. & Neutron spectroscopy & [137] \\
\hline $\begin{array}{l}\text { Nucleoside diphosphate } \\
\text { kinase }\end{array}$ & Haloarcula sp. & CD spectroscopy, crystal structure & [52] \\
\hline $\begin{array}{l}\text { Proliferating cell nuclear } \\
\text { antigen }\end{array}$ & Haloferax sp. & Crystal structure & {$[42]$} \\
\hline Protease & Halobacillus sp. & Fluorescence resonance energy transfer & [51] \\
\hline $\begin{array}{l}\text { TATA-box binding } \\
\text { protein }\end{array}$ & Pyrococcus sp. & $\begin{array}{l}\text { Analytical ultracentrifugation, isothermal titration } \\
\text { calorimetry }\end{array}$ & [54] \\
\hline $\begin{array}{l}\text { TATA-box binding } \\
\text { protein }\end{array}$ & Pyrococcus sp. & $\begin{array}{l}\text { Site-directed mutagenesis, isothermal titration } \\
\text { calorimetry }\end{array}$ & {$[55-57]$} \\
\hline Xylanase & Bacillus sp. & Crystal structure & [138] \\
\hline \multicolumn{4}{|l|}{ Cold active } \\
\hline Adenylate kinase & Bacillus sp. & Crystal structure & [85] \\
\hline Adenylate kinase & Marinibacillus sp. & Crystal structure, CD spectroscopy & [139] \\
\hline Alkaline phosphatase & Gadus sp. & Fluorescence spectroscopy & [140] \\
\hline Alkaline phosphatase & Antarctic strain TAB5 & Site-directed mutagenesis & {$[84,141]$} \\
\hline Alkaline phosphatase & Vibrio sp. & Mutagenesis, CD spectroscopy & {$[142]$} \\
\hline Aminopeptidase & Colwellia sp. & Crystal structure & [143] \\
\hline
\end{tabular}


Table 1 Extremophilic enzymes studied for function in low water activity (Continued)

\begin{tabular}{|c|c|c|c|}
\hline Aminopeptidase & Colwellia sp. & $\begin{array}{l}\text { Differential scanning calorimetry, fluorescence } \\
\text { spectroscopy }\end{array}$ & [144] \\
\hline$\alpha$-amylase & Alteromonas sp. & Crystal structure & {$[86]$} \\
\hline$\alpha$-amylase & Pseudoalteromonas sp. & $\begin{array}{l}\text { Mutagenesis, differential scanning calorimetry, } \\
\text { fluorescence spectroscopy }\end{array}$ & [145] \\
\hline$\alpha$-amylase & Pseudoalteromonas sp. & $\begin{array}{l}\text { Differential scanning calorimetry, fluorescence } \\
\text { spectroscopy }\end{array}$ & [79] \\
\hline$\alpha$-amylase & Pseudoalteromonas sp. & $\begin{array}{l}\text { Matrix assisted laser desorption ionization time-of-flight } \\
\text { mass spectrometry }\end{array}$ & [146] \\
\hline$\alpha$-amylase & Alteromonas sp. & $\begin{array}{l}\text { Mutagenesis, crystal structure, molecular dynamics } \\
\text { simulations }\end{array}$ & [147] \\
\hline $\begin{array}{l}\text { Aspartate } \\
\text { aminotransferase }\end{array}$ & Pseudoalteromonas sp. & $\begin{array}{l}\text { Homology modeling, CD and fluorescence } \\
\text { spectroscopy }\end{array}$ & [148] \\
\hline$\beta$-galactosidase & Arthrobacter sp. & Crystal structure & [149] \\
\hline$\beta$-lactamase & Pseudomonas sp. & Crystal structure & {$[87]$} \\
\hline Catalase & Vibrio sp. & $\begin{array}{l}\text { Differential scanning calorimetry, fluorescence } \\
\text { spectroscopy }\end{array}$ & [150] \\
\hline Catalase & Vibrio sp. & Crystal structure & {$[151]$} \\
\hline Chitinase & Arthrobacter sp. & $\begin{array}{l}\text { Homology-modeling, mutagenesis, fluorescence } \\
\text { spectroscopy }\end{array}$ & {$[77]$} \\
\hline Chitobiase & Arthrobacter sp. & Differential scanning calorimetry & {$[152]$} \\
\hline Citrate synthase & Antarctic bacterium DS2-3R & Crystal structure & [153] \\
\hline Citrate synthase & Arthrobacter sp. & Site-directed mutagenesis & [154] \\
\hline Citrate synthase & Sulfolobus sp. & Crystal structure & {$[155]$} \\
\hline Citrate synthase & Arthobacter sp., Pyrococcus sp. & Homology modeling & {$[156]$} \\
\hline Endonuclease I & Vibrio sp. & Crystal structure & {$[59]$} \\
\hline Esterase & Pseudoalteromonas sp. & $\begin{array}{l}\text { Fourier transform infrared spectroscopy, molecular } \\
\text { dynamics simulation }\end{array}$ & [78] \\
\hline Iron superoxide & Pseudoalteromonas sp. & Crystal structure, CD and fluorescence spectroscopy & [75] \\
\hline Lipase & Photobacterium sp. & Crystal structure & [157] \\
\hline Malate dehydrogenase & Aquaspirillium sp. & Crystal structure & {$[88]$} \\
\hline Nitrate reductase & Shewanella sp. & Homology modeling & [158] \\
\hline Pepsin & Trematomus sp. & Homology modeling & [159] \\
\hline Protease & Bacillus sp. & Homology modeling, mutagenesis, CD spectroscopy & {$[160]$} \\
\hline Protease & Pseudomonas sp. & Crystal structure & [161] \\
\hline Protease & Pseudoalteromonas sp. & Homology modeling, CD, fluorescence spectroscopy & [162] \\
\hline Protease & Bacillus sp. & Homology modeling, mutagenesis & [163] \\
\hline Protease & Vibrio sp. & Site-directed mutagenesis & [164] \\
\hline Protease & Bacillus sp. & Crystal structure & {$[165]$} \\
\hline Protease & Geomicrobium sp. & $\begin{array}{l}\text { Homology modeling, CD and fluorescence } \\
\text { spectroscopy }\end{array}$ & {$[166,167]$} \\
\hline Ribonuclease & Shewanella sp. & Site-directed mutagenesis, CD spectroscopy & {$[168]$} \\
\hline Superoxide dismutase & Aliivibrio sp. & Crystal structure, differential scanning calorimetry & [93] \\
\hline Subtilisin & Bacillus sp. & Site-directed mutagenesis & [169] \\
\hline $\begin{array}{l}\text { Triose phosphate } \\
\text { isomerase }\end{array}$ & Vibrio sp. & Crystal structures, calorimetry & [98] \\
\hline \multicolumn{4}{|l|}{ Organic solvent active } \\
\hline Alcohol dehydrogenase & Rhodococcus sp. & Crystal structure & [119] \\
\hline Protease & Pseudomonas sp. & Site-directed and random mutagenesis & {$[116,117]$} \\
\hline Protease & Pseudomonas sp. & Homology modeling & [118] \\
\hline
\end{tabular}




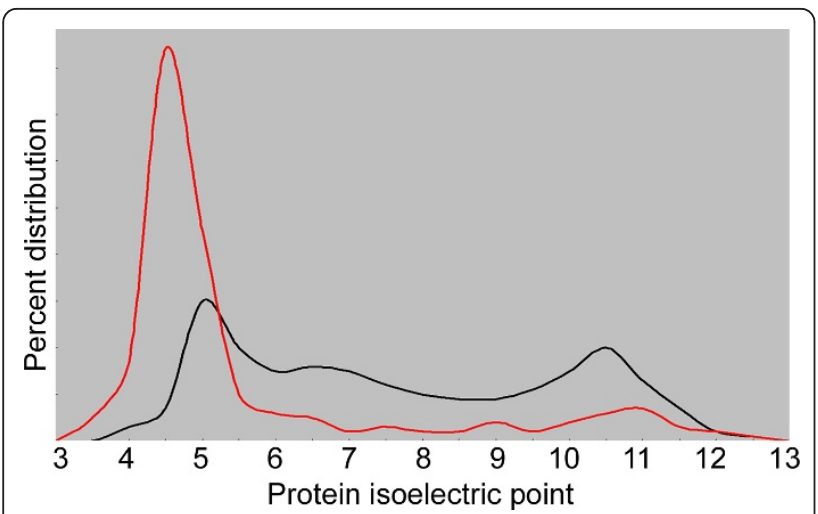

Figure 2 Distribution of protein isoelectric point in halophilic and non-halophilic organisms predicted from genome sequences (adapted from ref. 13). The percent of all predicted proteins is plotted versus their calculated isoelectric points. The distribution of protein isoelectric points for the halophile Halobacterium sp. NRC-1 (red) is skewed towards acidic range while those of non-halophiles (black) have a broader distribution of isoelectric points with an average of neutrality in most cases.

$\mathrm{X}$-ray and neutron diffraction structures have confirmed that the high content of acidic residues play significant roles in binding of essential water molecules and salt ions, preventing protein aggregation and providing flexibility to protein structure through electrostatic repulsion (Figure 3). For example, the structure of malate dehydrogenase from the extremely halophilic archaeaon Haloarcula marismortui received considerable attention from Mevarech and co-workers [40] and the group of Zaccai [19]. The presence of clusters of acidic residues has been observed in the crystal structure of dihydrofolate reductase (DHFR) and proliferating cell nuclear antigen (PCNA) from the extremely halophilic archaeaon Haloferax volcanii [41,42]. Crystal structure of the glucose dehydrogenase of the extremely halophilic archaeaon $H$. mediterranei has also contributed much information about halophilic adaptation and concluded that the surface of enzyme was predominantly acidic in nature and contributed to the halophilic characters of the enzyme [30]. In another study, Tadeo et al. [35] reported that by altering the amino acid composition at the protein surface, it is possible to modify the salt dependence of proteins and interconvert salt tolerant and non-tolerant proteins. Through the analysis of a large number of mutants, they concluded that the effect of salt on protein stability is largely independent of the total protein charge. In a recent study, a model of the recombinant esterase from $H$. marismortui, cloned and overexpressed in Escherichia coli, confirmed the enrichment of acidic residues and showed a high negative potential from clusters of aspartate and glutamate residues, with most acidic residues confined on the surface [43].
An interesting finding also apparent from the genomewide bioinformatic analysis of predicted proteins was the deficit of protein surface lysine residues in halophilic proteins $[13,27,33]$. This observation is consistent with the reduction in hydrophobic surfaces in halophilic proteins, resulting in increased hydration at the protein surface. This prediction was confirmed directly via the structure of glucose dehydrogenase from the extreme halophile $H$. mediterranei solved by Britton et al. [30], where lysine residues on the enzyme surface have their side chains buried and better ordered than those from non-halophiles (Figure 3). In halophilic proteins, lysine residues are often replaced by arginines, likely due to the greater hydrophilicity of the guanidinyl side chain, with a substantial role in maintaining the active protein structure $[11,30,35,38,44]$.

Halophilic proteins have also been found to contain a low content of bulky hydrophobic side chains on their surface, compared to non-halophilic proteins. The number of larger hydrophobic amino acid residues (phenylalanine, isoleucine, and leucine) is reduced compared to small (glycine and alanine) and borderline hydrophobic (serine and threonine) amino acid residues $[27,31-34,38,45]$. These findings are also consistent with increased flexibility, increased surface hydration, and reduced surface hydrophobicity of halophilic proteins.

In halophilic proteins, oppositely charged neighboring residues often interact to form salt bridges and these salt bridges play significant roles in protein folding, structure, and oligomerization (Figure 3). For example, the crystal structure of malate dehydrogenase from $H$. marismortui showed an increase in the number of salt bridges compared with the non-halophilic homologs, which enhanced enzyme stability at high salt concentrations [28]. This enzyme exists as a tetramer at high salt concentrations and dissociates into monomers as the salinity is reduced [46]. Similarly Madern et al. [47] have shown that isocitrate dehydrogenase from the halophilic archaeon $H$. volcanii exists as a dimer at high salt concentration but at low salt concentration it is irreversibly deactivated, due to dissociation of the dimer towards an inactive, partially folded monomeric species. Halobacterium sp. ferredoxin studied using CD and fluorescence techniques showed that the increase in salt concentration decreased electrostatic repulsion by ion binding, likely stabilizing oligomerization necessary for catalytic activity [48].

High salt concentrations generally enhance native conformation and functionality in halophilic proteins $[31,49,50]$. Salt concentrations may significantly affect the folding, conformation, subunit structure, and kinetics of halophilic proteins. Withdrawal of salt generally results in the gradual loss of protein structure and unfolding of halophilic proteins. Okamoto et al. [51] 


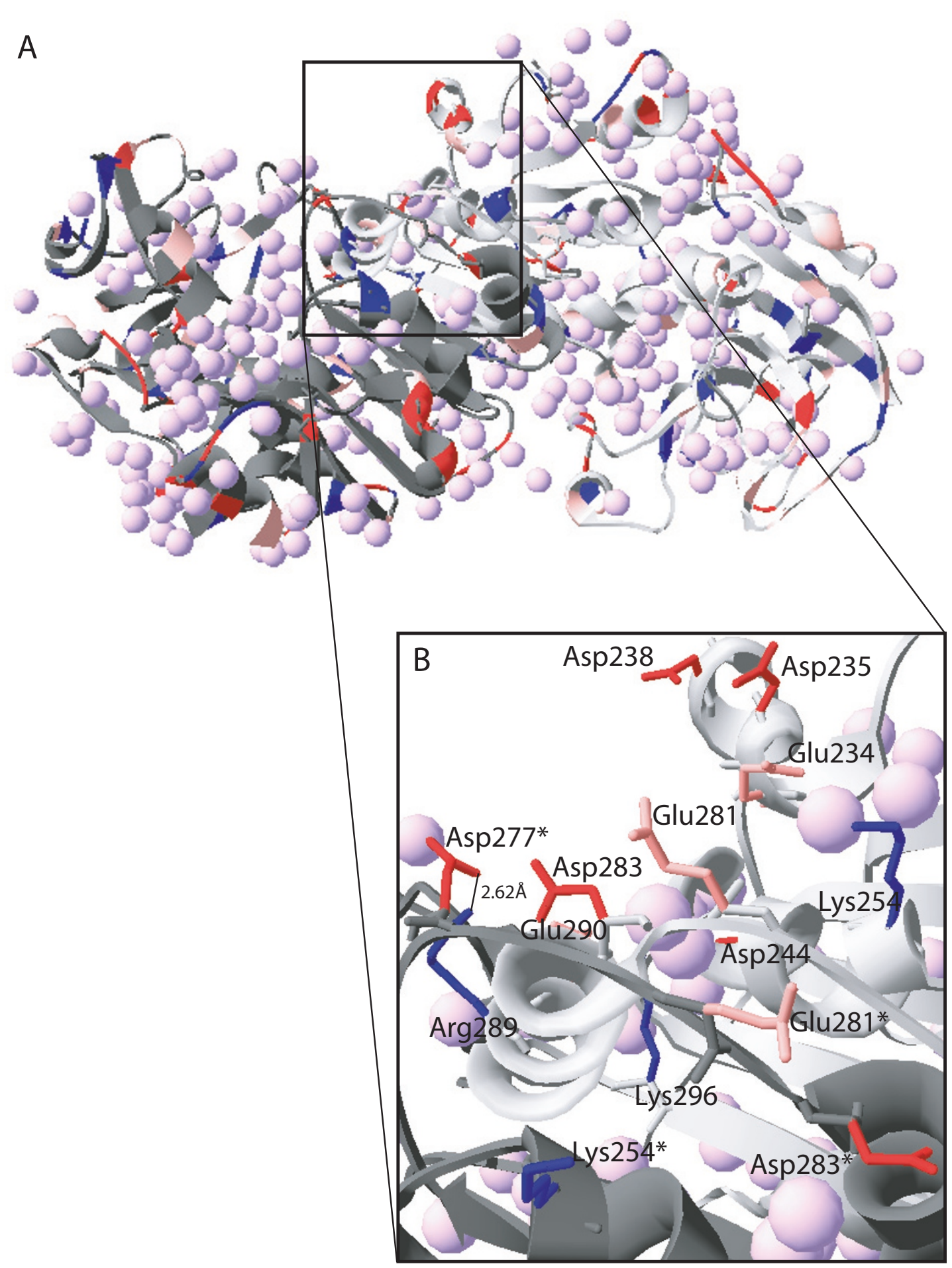

Figure 3 Structural features of an extremophilic glucose dehydrogenase. The protein structure (PDB ID:2B5V) [30] was downloaded from RCSB Protein Data Bank [123] and illustrated using DeepView Swiss-PdbViewer [124]. (A) Ribbon structure is shown with one subunit colored light gray and one subunit colored dark gray. Boxed region encompassing three $\alpha$-helices of one subunit and two partial $\alpha$-helices of the other subunit are shown in detail in part B. Acidic residues (aspartic acid and glutamic acid) are colored red and pink respectively, and basic residues (arginine and lysine) are colored dark blue and medium blue, respectively. Water molecules are colored light purple. (B) Expanded region showing a portion with side chains of exposed acidic residues and buried basic residues. Asterisk indicates residues of the dark gray subunit. An inter-subunit ion pair between Arg289 of one subunit and Asp277 of the other subunit is shown by a line labeled $2.62 \AA$, the distance between interacting atoms of the two residues. 
studied the role of salt on the kinetics of a high saltactive extracellular protease from the moderately halophilic bacterium Halobacillus sp. with fluorescence resonance energy transfer (FRET) and found that $\mathrm{NaCl}$ and other kosmotropic salts have a positive effect on catalytic activity of the enzyme. Their results suggested that these salts are excluded from the solvation shell of proteins because they have higher affinity for water than for the protein surface. Using far-ultraviolet circular dichroism (farUV-CD), Müller-Santos et al. [43] showed that in salt-free medium, an esterase from $H$. marismortui was completely unfolded and secondary structures appeared only in the presence of high concentrations of salt. The salt-dependent activity profiles of nucleoside diphosphate kinases from extremely halophilic archaea Haloarcula quadrata and $H$. sinaiiensis, have also been studied by farUV-CD spectroscopy, with salt-dependent oligomerization observed only for the latter [52]. Srimathi et al. [53] investigated a cold adapted amylase from the psychrophile Pseudoalteromonas haloplanktis by $C D$ and fluorescence techniques. This cold-active amylase showed increased activity and improved folding at higher concentrations of salt similar to halophilic enzymes, indicating similar mechanisms of enhanced activity in both high salt and low temperature conditions.

Salt is also known to play a critical role in proteinDNA interactions. O'Brien et al. [54] studied the effect of salt on the thermodynamic-structural relationship of the binding of TATA box-binding protein (TBP) from Pyrococcus woesei, a moderately halophilic and hyperthermophilic organism, to its DNA binding site. This group hypothesized that uptake of cations and discharge of water accompanies protein-DNA complex formation. Subsequently Bergqvist et al. [55] used sitedirected mutagenesis to change cation binding sites, i.e. negatively charged, acidic glutamate residues on the protein surface. Consistent with the hypothesis, they found that some of the mutants were able to convert the halophilic, relatively salt insensitive TBP into non-halophilic, salt sensitive variants [56,57].

While the underlying molecular mechanisms of halophilic protein function are still not fully understood, available studies have begun to shed considerable light on their strategies for adaptation to high salinity and relatively low water activity. Based on the many available studies, clustered surface negative charges, decreased hydrophobicity at the surface of the protein, and enrichment of salt bridges appear to be general strategies for improving the function of halophilic proteins in high salt, low water conditions. However, these mechanisms may not be universal $[58,59]$, and additional research will continue to provide further insights into their function and activity. It is clear, however, that enzymes isolated from halophiles possess extraordinary structural and catalytic properties that allow function at low water activity. These exceptional biomolecules have great potential for applications to many biotechnological and industrial processes (Table 2).

\section{Cold active enzymes}

Like high salinity, cold temperatures also critically affect the properties and structures of enzymes as well as the surrounding water. Cold temperatures affect the dynamic activity of bulk water as well as the spheres of hydration surrounding the protein surface [60]. Since water acts as a lubricant, easing the essential peptide amide-carbonyl hydrogen bonding dynamic, the effects of water are highly dependent on the temperature [61-63]. Dependence of the strength of aqueous hydrogen bonds on temperature is neither linear nor monotonic but unimodal, with the maximum density for pure water at approximately $4^{\circ} \mathrm{C}$. Broken hydrogen bonds are found in high-density water while strong networks of hydrogen bonds are found in low-density water [63]. Deficiency or disturbance of hydrogen bonds and water networks around the protein may be linked to the loss of biological activity and protein denaturation at low temperatures [64].

As temperature decreases, the water molecules surrounding the protein surface become more ordered and thereby less associated with the protein, eventually pushing the system equilibrium toward the unfolded or denatured state. This change in protein structure is driven by an increase in hydration energies of non-polar groups at lower temperature $[65,66]$. The hydration energies of cold-active enzymes are generally less affected by lower temperature, and their lower inherent surface hydrophobicity is less sensitive than mesophilic proteins, keeping their structures more intact [67]. In effect, cold active proteins are able to hold on more tightly to the available water, similar to salt adapted proteins.

Temperature and viscosity of the medium are inversely related, with viscosity halved when the temperature is reduced from $37^{\circ} \mathrm{C}$ to $0^{\circ} \mathrm{C}$ [68]. Low temperatures therefore reduce the speed of reactions at least in part due to the strong effect of temperature on viscosity of the medium [68-71]. Based on biophysical considerations, reaction rates are predicted to decrease 2-3 fold for every $10^{\circ} \mathrm{C}$ decrease in temperature, according to the Arrhenius equation [72]. As a result, the effect of reduced temperature on enzyme activity is very significant, and the design of cold-active enzymes must have some structural adaptations to maintain the level of 'breathing' necessary for catalysis $[73,74]$.

Studies of cold active enzymes have suggested that both an increase in interactions with the solvent and an 
Table 2 Extremophilic enzymes in biotechnology

\begin{tabular}{|c|c|c|c|c|c|c|}
\hline \multirow[t]{2}{*}{ Name } & \multirow[t]{2}{*}{ Organism } & \multicolumn{3}{|c|}{ Activity } & \multirow[t]{2}{*}{ Application(s) } & \multirow{2}{*}{$\begin{array}{l}\text { Reference } \\
\text { (s) }\end{array}$} \\
\hline & & Salt & Cold & $\begin{array}{l}\text { Organic } \\
\text { solvent }\end{array}$ & & \\
\hline Amylase & Pseudoalterimonas sp. & + & & & $\begin{array}{l}\text { *Saccharification of marine microalgae, saccharification of marine } \\
\text { microalgae producing ethanol }\end{array}$ & {$[170]$} \\
\hline Amylase & Halococcus sp. & + & & + & $\begin{array}{l}\text { Starch hydrolysis in industrial processes in saline and organic } \\
\text { solvent medium }\end{array}$ & [171] \\
\hline Amylase & Streptomyces sp. & + & & & Detergent formulations & {$[172]$} \\
\hline $\begin{array}{l}\text { Alcohol } \\
\text { dehydrogenase }\end{array}$ & Rhodococcus sp. & & & + & $\begin{array}{l}\text { *Enantioselective oxidation of sec-alcohol and the asymmetric } \\
\text { reduction of ketones }\end{array}$ & [173] \\
\hline $\begin{array}{l}\text { Alkaline } \\
\text { phosphatase }\end{array}$ & $\begin{array}{l}\text { Antarctic bacteria strain } \\
\text { HK47 }\end{array}$ & & + & & *Radioactive end-labeling of nucleic acids & [174] \\
\hline $\begin{array}{l}\text { Alkaline } \\
\text { phosphatase }\end{array}$ & Antarctic strain TAB5 & & + & & ${ }^{*}$ Dephosphorylation of DNA vectors & [84] \\
\hline$\beta$-galactosidase & Pseudoalteromonas sp. & & + & & *Lactose hydrolysis & {$[175]$} \\
\hline$\beta$-galactosidase & Kluyveromyces sp. & & & + & *Synthesis of galacto-oligosaccharides from lactose & {$[176]$} \\
\hline$\beta$-galactosidase & Arthrobacter sp. & & + & & $\begin{array}{l}\text { Lactose hydrolysis at low temperature, production of ethanol from } \\
\text { lactose-based feedstock }\end{array}$ & {$[177]$} \\
\hline$\beta$-galactosidase & Bacillus sp. & & & + & *Synthesis of $\mathrm{N}$-acetyl-lactosamine & {$[178]$} \\
\hline Chitinase & Halobacterium sp. & + & & + & Oligosaccharide synthesis & {$[179]$} \\
\hline Chitinase & Virgibacillus sp. & + & & & $\begin{array}{l}\text { Bioconversion of chitin from fish, crab or shrimp; treatment of } \\
\text { chitinous waste }\end{array}$ & [180] \\
\hline $\begin{array}{l}\text { Cholesterol } \\
\text { oxidase }\end{array}$ & Pseudomonas sp. & & & + & Organic synthesis & [181] \\
\hline Glutaminase & Micrococcus sp. & + & & & Flavor-enhancing in food industries, antileukaemic agent & [182] \\
\hline Esterase & Pyrobaculum sp. & & & + & Organic synthesis & [183] \\
\hline Esterase & Pseudoalteromonas sp. & & + & & Hydrolyzing esters of medical relevance & [184] \\
\hline Lipase & Candida sp. & & + & & $\begin{array}{l}\text { *Organic synthesis related to food/feed processing, } \\
\text { pharmaceuticals or cosmetics }\end{array}$ & [185] \\
\hline Lipase & Rhizopus sp., Candida sp. & & & + & Biodiesel production & [101-103] \\
\hline Lipase & Candida sp. & & & + & Biodiesel production & {$[104,105]$} \\
\hline Lipase & $\begin{array}{l}\text { Pseudoalteromonas sp., } \\
\text { Psychrobacter sp., Vibrio sp. }\end{array}$ & & + & + & $\begin{array}{l}\text { Detergent formulations and bioremediation of fat-contaminated } \\
\text { aqueous systems }\end{array}$ & [186] \\
\hline Lipase & Staphylococcus sp. & & + & & Detergent formulations & {$[187]$} \\
\hline Lipase & Psuedomonas sp. & & & + & Biodiesel production & {$[106,107]$} \\
\hline Lipase & Salinivibrio sp. & + & & & Detergent formulations and fatty acid degradations & [188] \\
\hline Lipase & Psuedomonas sp. & & & + & $\begin{array}{l}\text { Solvent bioremediation, biotransformations and detergent } \\
\text { formulations }\end{array}$ & [189] \\
\hline Lipase & Marinobacter sp. & + & & + & *Hydrolysis of fish oil into free eicosapentaenoic acid & [190] \\
\hline Nuclease & Micrococcus sp. & + & & & *Production of the flavoring agent 5 -guanylic acid & [191] \\
\hline Pectinase & Pseudoalteromonas sp. & & + & + & $\begin{array}{l}\text { Enhancing extraction yield, clarification, } \\
\text { and taste of fruit juices }\end{array}$ & [192] \\
\hline Protease & Halobacterium sp. & + & & + & *Peptide synthesis & {$[193,194]$} \\
\hline Protease & Pseudomonas sp. & & & + & $\begin{array}{l}\text { *Synthesis of N-carbobenzoxy-L-arginine-L-leucine amide, } \mathrm{N} \text { - } \\
\text { carbobenzoxy-L-alanine-L-leucine amide and aspartame precursor }\end{array}$ & {$[195,196]$} \\
\hline Protease & Pseudomonas sp. & & & + & Peptide synthesis & [197] \\
\hline Protease & Bacillus sp. & & + & & ${ }^{*}$ Cleansing of contact lenses & [198] \\
\hline Protease & Natrialba sp. & + & & + & *Synthesis of tripeptide Ac-Phe-Gly-Phe-NH${ }_{2}$ & [199] \\
\hline Protease & Halobacterium sp. & + & & & *Fish sauce preparation & [200] \\
\hline Protease & Geomicrobium sp. & + & & + & Peptide synthesis, detergent formulations & {$[201,202]$} \\
\hline Xylanase & Pseudoalteromonas sp. & & + & & *Baking industry for increasing loaf volume & {$[203,204]$} \\
\hline Xylanase & Bacillus sp. & + & & & Xylan biodegradation in pulp and paper industry & {$[205,206]$} \\
\hline
\end{tabular}

* applications established in laboratory and/or industry 
increase in structural flexibility contribute to maintaining catalytic activity at lower temperatures [14,73,75-83] (Table 1). Aurilia et al. [78] used Fourier transform infrared spectroscopy (FTIR) and molecular dynamics simulations to investigate a cold active esterase from $P$. haloplanktis and found that the flexibility of the protein loop near the active site plays a crucial role in its function. An $\alpha$-amylase from the same organism was investigated by D'Amico et al. [79] and shown using differential scanning calorimetry and fluorescence spectroscopy to have high conformational flexibility and electrostatic potential at the protein surface, which lowers activation energy for hydrolysis. The temperature dependence of alkaline phosphatase from the Antarctic strain TAB5 was studied by selection of thermostable and thermolabile variants. The study showed that cold activity is sensitive to slight changes in the protein sequence, particularly in residues located within or close to the active site of the enzyme [84].

There are relatively few solved three-dimensional structures of cold-active proteins compared to mesophilic or thermophilic proteins. While overall structures of cold adapted proteins are generally almost identical to mesophilic and thermophilic homologs [76], variations that are observed confirm an overall increase in protein flexibility and solvent interactions. For example, the crystal structures of cold active superoxide dismutase from $P$. haloplanktis and Alivibrio salmonicida were compared with the mesophilic homolog from E. coli. Both cold-active superoxide dismutases showed an increased flexibility of the active site residues with respect to their mesophilic homologue [75]. Bae and Phillips [85] compared the crystal structures of adenylate kinases from the psychrophile B. globisporus and the mesophile B. subtilis with the thermophilic B. stearothermophilus enzyme. They concluded that the maintenance of proper flexibility is critical for the cold active proteins to function at their environmental temperatures. Similarly the crystal structure of Alteromonas haloplanctis $\alpha$-amylase and Pseudomonas fluorescens $\beta$ lactamase showed a decrease in the number of hydrogen-bonds favoring more flexibility in these cold-active enzymes [86,87]. The crystal structure of a cold active malate dehydrogenase from Aquaspirillium arcticum showed similar features to be responsible for cold activity, including an increased flexibility around the active site region, more favorable surface charge distribution for substrate and cofactor interactions, and reduced intersubunit ion pair interactions [88].

A bioinformatic study of amino acid contacts that differ between proteins adapted to different temperatures, which included nearly 400 psychrophilic proteins, found that interactions with the solvent at the protein surface play an important role in temperature adaptation [89].
Additional bioinformatic and experimental studies have also suggested that the temperature-dependent activity of cold active enzymes may be altered by changing the amino acid composition, especially the overall protein charge, decreasing the hydrophobicity in the core of the enzyme, or decreasing the number of hydrogen bonds, salt bridges, or bound ions at the surface [72,90-92].

Amino acids present on the protein surface of cold active enzymes have been shown to play critical roles in both activity in cold and in high salinity, with increased activity and improved folding at higher concentrations of salt [53,59]. Moreover, the crystal structure of a coldactive iron superoxide dismutase from the A. salmonicida also showed an increase in the net negative charge on the surface of cold-active iron superoxide dismutase [93]. These findings and others [94-97] suggest that solvent interactions of cold active enzymes display remarkable similarity to salt adapted enzymes.

While the adaptive mechanisms of cold active proteins are still under investigation, the best understood mechanisms include increased conformational flexibility at the expense of stability and enhanced interactions with the solvent. To increase flexibility, many structural modifications and the disappearance of discrete stabilizing interactions (electrostatic interactions and an improved interaction of surface side chains with the solvent) have been observed. While nearly all cold active enzymes studied to date have shown these tendencies, there are examples of unusual enzymes, e.g. enzymes displaying rapid kinetics, which display temperature independent characteristics. Triosephosphate isomerase from Vibrio marinus is an example of a temperature independent enzyme [98]. The number of cold active proteins studied is expanding and additional future research including comparisons with closely related mesophilic homologs will provide further insights into enzymology at low temperature. The novel properties of cold active enzymes are likely to be valuable for a variety of applications in biotechnology and industry [99].

\section{Enzyme function in organic solvents}

One of the most useful outcomes of a better understanding of enzyme-solvent interactions is the potential engineering of new and more effective catalysts functioning in non-aqueous environments. Such enzymes may be useful for both biofuel and bioenergy applications, where large quantity of ethanol or other organic solvents are produced [100-107], and for synthetic chemistry, especially when catalysis of desired chemical reactions requires the presence of organic solvents $[108,109]$. Organic solvents in the reaction mixture increase the solubility of hydrophobic substrates, and have the potential to improve the kinetic equilibrium and increase the yield and specificity of the product. 
However, limiting the disruption of molecular interactions in enzymes by organic solvents and the concomitant loss of activity remains a significant challenge.

A main factor responsible for loss of enzyme activity in organic solvents is the loss of crucial water molecules $[109,110]$. The low water content restrains protein conformation mobility and affects $\mathrm{K}_{\mathrm{m}}$ and $\mathrm{V}_{\max }$ values [111]. This rigidity increases resistance to thermal vibrations and reduces the enzyme-substrate interactions, leading to a reduced catalytic rate $[112,113]$. Loss of water can also disrupt hydrogen bond formation between protein subunits on the exterior surface and active site interactions in the interior of proteins may be weakened. The presence of organic solvents can cause disruption of the forces important to the hydrophobic core due to the increased hydrophobicity of the medium. Low water activity may limit diffusion of substrates and stabilize the ground state of the enzyme or change the enzyme conformation altogether. Enzymes in nonaqueous systems can be active provided that the enzyme surface and the active site region are well hydrated [114].

The polarity of organic solvents is the most important factor in the balance between stabilization and inactivation of enzymes. Co-solvents systems (water plus watermiscible organic solvents), organic aqueous biphasic systems (water plus water-immiscible organic solvents), nearly anhydrous systems, and reverse micelles may be the result of addition of organic solvents with water. The relative proportion of organic solvent and water depends on the miscibility of the components [109-115]. Highly polar, miscible organic solvents may strip the hydration layer from the enzyme surface, affecting enzyme flexibility and catalytic activity. Hydrophobic solvents, in contrast, may form a two-phase non-homogeneous system, leaving the hydration shell of the protein intact. However, they may sequester substrate away from the enzyme, depending on solubility and partitioning between phases. For improved activity in two-phase systems, a microenvironment or surface where favorable conditions (high enzyme activity, high substrate concentration, and low product solubility) driving high reaction rates may be desirable.

Published studies of the mechanism of adaptation of enzymes to function in organic solvent are relatively few. Ogino et al. [116,117] investigated the mechanism of organic solvent tolerance in a Pseudomonas aeruginosa PST-01 protease by site-directed and random mutagenesis. They reported that the disulfide bonds and amino acid residues located on the surface of the molecule play important roles in organic solvent stability of the enzymes. The structural analysis of organic solvent effects on a protease from a similar $P$. aeruginosa strain also identified two disulfide bonds as well as a number of hydrophobic clusters at the protein surface. These hydrophobic patches and disulfide bonds were proposed to be responsible for the solvent-stable nature of the enzyme [118]. Recently, Karabec et al. [119] solved the crystal structure of alcohol dehydrogenase from Rhodococcus ruber DSM 44541 and suggested that salt-bridges play a significance role in the stability of this enzyme in non-aqueous media.

Organic solvent mediated enzymatic reactions have many advantages over aqueous enzymatic reactions: (i) increased solubility of apolar substrate and alteration in substrate specificity, (ii) enhanced regio-and stereoselectivity, (iii) absence of racemization, (iv) lack of requirement of side chain protection, (v) reduced water activity altering the hydrolytic equilibrium, (vi) elimination of microbial contamination, and (vii) suppression of unwanted water-dependent side reactions $[108,109,114,115]$. Additionally, enzymes in organic solvents tend to be more rigid than in water (due to increased electrostatic and hydrogen bonding interactions among the surface residues of enzyme) and provide the possibility of techniques such as molecular imprinting [109]. In molecular imprinting, the enzyme solution is freeze-dried with a ligand ("imprinter") that locks the enzymes into a catalysis favorable condition during lyophilization and enhances the enzyme activity in organic solvents [120]. In some cases, it has been found that molecular imprinting increases enzyme activity in organic solvents when co-lyophilized with an inorganic salt such as $\mathrm{KCl}$. $\mathrm{KCl}$ prevents the reversible denaturation of proteins and produces a strong additive activation effect during the drying process [121]. Among the disadvantages of non-aqueous organic enzyme catalysis, the loss of catalytic activity is the most common. Many enzymatic reactions are also susceptible to substrate and/or product inhibition, and expensive natural cofactors for enzyme activity may be required for full activity. Finally, labor and cost-intensive preparation of biocatalysts and enzymes may require narrow operation parameters, limiting the value of some enzymes that may be active in the presence of organic solvents $[109,122]$. However, the potential for organic solvent mediated enzyme catalysis to enable desirable biotechnological aims remains a major motivating factor for additional research.

\section{Conclusion}

Extremophilic salt adapted and cold active enzymes have expanded our understanding of enzyme stability and activity mechanisms, protein structure-function relationships, and enzyme engineering and evolution. The still emerging understanding of protein-solvent interactions are likely to aid in development of new catalysts for use in novel synthetic applications, including enzymes 
operating in low water activity and organic solvents, and in the development of efficient catalytic systems active in organic solvents for applications in bioenergy and biotechnology.

\section{Acknowledgements}

This work was funded by NSF grant MCB-0450695, Henry M Jackson Foundation grant HU0001-09-1-0002-660883, and the National Aeronautics and Space Administration grant NNX10AP47G to SD. RK was partially supported by an ASM International Fellowship for Asia.

\section{Author details}

'Department of Microbiology and Immunology, University of Maryland School of Medicine, Baltimore, MD, USA. ${ }^{2}$ Institute of Marine and Environmental Technology, University System of Maryland, Baltimore, MD, USA.

\section{Authors' contributions}

The manuscript was drafted by RK and revised and finalized together with MDC and SD. All authors have read and approved the final manuscript.

\section{Competing interests}

The authors declare that they have no competing interests.

Received: 14 November 2011 Accepted: 2 February 2012

Published: 2 February 2012

\section{References}

1. Hough DW, Danson MJ: Extremozymes. Curr Opin Chem Biol 1999, 1:39-46.

2. Gomes J, Steiner W: The biocatalytic potential of extremophiles and extremozymes. Food Technol Biotechnol 2004, 42:223-235.

3. Vieille C, Zeikus GJ: Hyperthermophilic enzymes: sources, uses, and molecular mechanisms for thermostability. Microbiol Mol Biol Rev 2001, 1:1-43.

4. Bull AT, Ward AC, Goodfellow M: Search and discovery strategies for biotechnology: the paradigm shift. Microbiol Mol Biol Rev 2000, 3:573-606.

5. Iyer PV, Ananthanarasyan L: Enzyme stability and stabilization-aqueous and non-aqueous environment. Process Biochem 2008, 43:1019-1032.

6. Kaul P, Asano Y: Strategies for discovery and improvement of enzyme function: state of the art and opportunities. Microb Biotechnol 2011, doi: 10.1111/j.1751-7915.2011.00280.x.

7. Adams MWW, Perler FB, Kelly RM: Extremozymes: Expanding the limits of biocatalysis. Nat Biotechnol 1995, 13:662-668.

8. DasSarma P, Coker JA, Huse V, DasSarma S: Halophiles, Biotechnology. In Encyclopedia of Industrial Biotechnology, Bioprocess, Bioseparation, and Cell Technology. Edited by: Flickinger MC. Hoboken, NJ: John Wiley and Sons; 2010:2769-2777.

9. Bowers K, Mesbah NM, Wiegel J: Biodiversity of poly-extremophilic bacteria: Does combining the extremes of high salt, alkaline $\mathrm{pH}$ and elevated temperature approach a physico-chemical boundary for life? Saline Syst 2009, 5:9-17.

10. Marhuenda-Egea FC, Bonete MJ: Extreme halophilic enzymes in organic solvents. Curr Opin Biotechnol 2002, 13:385-389.

11. Pire C, Marhuenda-egea FC, Esclapez J, Alcaraz L, Ferrer J, Bonete MJ: Stability and enzymatic studies of glucose dehydrogenase from the Archaeon Haloferax mediterranei in reverse micelles. Biocatal Biotransform 2004, 22:17-23.

12. Danson MJ, Hough DW: The structural basis of protein halophilicity. Comp Biochem Physiol A Physiol 1997, 117:307-312.

13. Kennedy SP, Ng WW, Salzberg SL, Hood L, DasSarma S: Understanding the adaptation of Halobacterium species NRC-1 to its extreme environment through computational analysis of its genome sequence. Genome Res 2001, 11:1641-1650.

14. Siddiqui KS, Cavicchioli R: Cold-adapted enzymes. Annu Rev Biochem 2006, 75:403-433.

15. Kuntz ID: Hydration of macromolecules IV Polypeptide conformation in frozen solutions. J Am Chem Soc 1971, 93:516-518.

16. Saenger W: Structure and dynamics of water surrounding biomolecules. Annu Rev Biophys Biophys Chem 1987, 16:93-114.
17. Persson E, Halle B: Cell water dynamics on multiple time scales. Proc Natl Acad Sci USA 2008, 17:6266-6271.

18. Spitzer J: From water and ions to crowded biomacromolecules: In vivo structuring of a prokaryotic cell. Microbiol Mol Biol R 2011, 3:491-506.

19. Zaccai G: The effect of water on protein dynamics. Philos Trans $R$ Soc Lond B Biol Sci 2004, 359:1269-1275.

20. Mountain RD, Thirumalai $\mathrm{D}$ : Alterations in water structure induced by guanidinium and sodium ions. J Phys Chem 2004, 108:19711-19716.

21. Mancinelli R, Botti A, Bruni F, Ricci MA, Soper AK: Hydration of sodium, potassium, and chloride ions in solution and the concept of structure maker/breaker. Phys Chem 2007, 111:13570-13577.

22. Bakker HJ: Water dynamics: Ion-ing out the details. Nature Chemistry 2009, 1:24-25.

23. Irimia A, Ebel C, Madern D, Richard SB, Cosenza LW, Zaccaï G, Vellieux FM: The oligomeric states of Haloarcula marismortui malate dehydrogenase are modulated by solvent components as shown by crystallographic and biochemical studies. J Mol Biol 2003, 3:859-873.

24. Dennis PP, Shimmin LC: Evolutionary divergence and salinity-mediated selection in halophilic archaea. Microbiol Mol Biol Rev 1997, 61:90-104.

25. Sedlák E, Stagg L, Wittung-Stafshede P: Role of cations in stability of acidic protein Desulfovibrio desulfuricans apoflavodoxin. Arch Biochem Biophys 2008, 1:128-135.

26. Ortega G, Laín A, Tadeo X, López-Méndez B, Castaño D, Millet O: Halophilic enzyme activation induced by salts. Scientific Reports 2011, 1:6.

27. Paul S, Bag SK, Das S, Harvill ET, Dutta C: Molecular signature of hypersaline adaptation: Insights from genome and proteome composition of halophilic prokaryotes. Genome Biol 2008, 9:R70.

28. Dym O, Mevarech M, Sussman JL: Structural features that stabilize halophilic malate dehydrogenase from an archaebacterium. Science 1995, 267:1344-1346.

29. Frolow F, Harel M, Sussman JL, Mevarech M, Shoham M: Insights into protein adaptation to a saturated salt environment from the crystal structure of a halophilic 2Fe-2S ferredoxin. Nature Struct Biol 1996, 3:452-458.

30. Britton KL, Baker PJ, Fisher M, Ruzheinikov S, Gilmour DJ, Bonete MJ, Ferrer J, Pire C, Esclapez J, Rice DW: Analysis of protein solvent interactions in glucose dehydrogenase from the extreme halophile Haloferax mediterranei. Proc Natl Acad Sci USA 2006, 103:4846-4851.

31. Lanyi JK: Salt dependent properties of proteins from extremely halophilic bacteria. Bacteriol Rev 1974, 38:272-290.

32. Madern D, Ebel C, Zaccai G: Halophilic adaptation of enzymes. Extremophiles 2000, 4:91-98.

33. Fukuchi S, Yoshimune K, Wakayama M, Moriguchi M, Nishikawa K: Unique amino acid composition of proteins in halophilic bacteria. J Mol Biol 2003, 327:347-357.

34. Bolhuis A, Kwan D, Thomas JR: Halophilic adaptations of proteins. In Protein adaptation in extremophiles. Edited by: Siddiqui KS, Thomas T. New York: Nova Science Publishers Inc USA; 2008:71-104.

35. Tadeo X, López-Méndez B, Triqueros T, Laín A, Castaño D, Millet O: Structural basis for the amino acid composition of proteins from halophilic archaea. PLOS Biol 2009, 7:e1000257.

36. Ishibashi M, Tokunaga H, Hiratsuka K, Yonezawa Y, Tsurumaru H, Arakawa T, Tokunaga $\mathrm{M}: \mathrm{NaCl}$-activated nucleoside diphosphate kinase from extremely halophilic archaeon, Halobacterium salinarum, maintains native conformation without salt. FEBS Lett 2001, 493:134-138.

37. De Castro RE, Ruiz DM, Giménez MI, Silveyra MX, Paggi RA, MaupinFurlow JA: Gene cloning and heterologous synthesis of a haloalkaliphilic extracellular protease of Natrialba magadii (Nep). Extremophiles 2008, 5:677-687.

38. Kastritis PL, Papandreou NC, Hamodrakas SJ: Haloadaptation: insights from comparative modeling studies of halophilic archaeal DHFRs. Int I Biol Macromol 2007, 41:447-453.

39. Elcock AH, McCammon JA: Electrostatic contributions to the stability of halophilic proteins. J Mol Biol 1998, 4:731-748.

40. Mevarech M, Frolow F, Gloss LM: Halophilic enzymes: Proteins with a grain of salt. Biophys Chem 2000, 86:155-164.

41. Pieper U, Kapadia G, Mevarech M, Herzberg O: Structural features of halophilicity derived from the crystal structure of dihydrofolate reductase from the Dead Sea halophilic archaeon, Haloferax volcanii. Structure 1998, 6:75-88. 
42. Winter JA, Christofi P, Morroll S, Bunting KA: The crystal structure of Haloferax volcanii proliferating cell nuclear antigen reveals unique surface charge characteristics due to halophilic adaptation. BMC Struct Biol 2009, 9:55

43. Müller-Santos M, de Souza EM, Pedrosa Fde O, Mitchell DA, Longhi S, Carrière F, Canaan S, Krieger N: First evidence for the salt-dependent folding and activity of an esterase from the halophilic archaea Haloarcula marismortui. Biochim Biophys Acta 2009, 1791:719-729.

44. Esclapez J, Pire C, Bautista V, Martínez-Espinosa RM, Ferrer J, Bonete MJ: Analysis of acidic surface of Haloferax mediterranei glucose dehydrogenase by site-directed mutagenesis. FEBS Lett 2007, 581:837-842.

45. Rao JKM, Argos P: Structural stability of halophilic proteins. Biochemistry 1981, 20:6536-6543.

46. Zaccai G, Cendrin F, Haik Y, Borochov N, Eisenberg H: Stabilization of halophilic malate dehydrogenase. J Mol Biol 1989, 208:491-500.

47. Madern D, Camacho M, Rodríguez-Arnedo A, Bonete MJ, Zaccai G: Saltdependent studies of NADP-dependent isocitrate dehydrogenase from the halophilic archaeon Haloferax volcanii. Extremophiles 2004, 5:377-384.

48. Bandyopadhyay AK, Sonawat HM: Salt dependent stability and unfolding of [Fe2-S2] ferredoxin of Halobacterium salinarum: Spectroscopic investigations. Biophys J 2000, 79:501-510.

49. Rao L, Zhao X, Pan F, Li Y, Xue Y, Ma Y, Lu JR: Solution behavior and activity of a halophilic esterase under high salt concentration. PLOS One 2009, 9:e6980.

50. Jolley KA, Russell RJ, Hough DW, Danson MJ: Site-directed mutagenesis and halophilicity of dihydrolipoamide dehydrogenase from the halophilic archaeon, Haloferax volcanii. Eur J Biochem 1997, 2:362-368.

51. Okamoto DN, Kondo MY, Santos JA, Nakajima S, Hiraga K, Oda K, Juliano MA, Juliano L, Gouvea IE: Kinetic analysis of salting activation of a subtilisin-like halophilic protease. Biochim Biophys Acta 2009, 1794:367-373.

52. Yamamura A, Ichimura $T$, Kamekura M, Mizuki T, Usami R, Makino T, Ohtsuka J, Miyazono K, Okai M, Nagata K, Tanokura M: Molecular mechanism of distinct salt-dependent enzyme activity of two halophilic nucleoside diphosphate kinases. Biophys J 2009, 96:4692-4700.

53. Srimathi S, Jayaraman G, Feller G, Danielsson B, Narayanan PR: Intrinsic halotolerance of the psychrophilic alpha-amylase from Pseudoalteromonas haloplanktis. Extremophiles 2007, 11:505-515.

54. O'Brien R, DeDecker B, Fleming K, Sigler PB, Ladbury JE: The effects of salt on the TATA binding protein-DNA interaction from a hyperthermophilic archaeon. J Mol Biol 1998, 279:117-125.

55. Bergqvist S, O'Brien R, Ladbury JE: Site-specific cation binding mediates TATA binding protein-DNA interaction from a hyperthermophilic archaeon. Biochemistry 2001, 40:2419-2425.

56. Bergqvist $\mathrm{S}$, Williams MA, O'Brien R, Ladbury JE: Reversal of halophilicity in a protein-DNA interaction by limited mutation strategy. Structure 2002, 10:629-637.

57. Bergqvist S, Williams MA, O'Brien R, Ladbury JE: Halophilic adaptation of protein-DNA interactions. Biochem Soc Trans 2003, 31:677-680.

58. Sivakumar N, Li N, Tang JW, Patel BK, Swaminathan K: Crystal structure of AmyA lacks acidic surface and provide insights into protein stability at poly-extreme condition. FEBS Lett 2006, 11:2646-2652.

59. Altermark B, Helland R, Moe E, Willassen NP, Smalås AO: Structural adaptation of endonuclease I from the cold-adapted and halophilic bacterium Vibrio salmonicida. Acta Crystallogr D Biol Crystallogr 2008, 64:368-376.

60. Zhong D, Pal SK, Zewail AH: Biological water: A critique. Chem Phys Lett 2010, 503:1-11

61. Fernández A, Scheraga HA: Insufficiently dehydrated hydrogen bonds as determinants of protein interactions. Proc Natl Acad Sci USA 2003, 100:113-118

62. Kurkal-Siebert V, Daniel RM, L Finney J, Tehei M, Dunn RV, Smith JC: Enzyme hydration, activity and flexibility: A neutron scattering approach. J Non-Cryst Solids 2006, 352:4387-4393.

63. Chaplin M: Do we underestimate the importance of water in cell biology? Nat Rev Mol Cell Biol 2006, 11:861-866.

64. Koizumi M, Hirai H, Onai T, Inoue K, Hirai M: Collapse of the hydration shell of a protein prior to thermal unfolding. J Appl Cryst 2007, 40 s175-s178.

65. Lopez CF, Darst RK, Rossky PJ: Mechanistic elements of protein cold denaturation. J Phys Chem B 2008, 112:5961-5967.
66. Dias CL, Ala-Nissila T, Wong-ekkabut J, Vattulainen I, Grant M, Karttunen M The hydrophobic effect and its role in cold denaturation. Cryobiol 2010, 60:91-99.

67. Fields PA: Protein function at thermal extremes: balancing stability and flexibility. Comp Biochem Physiol Pt A 2001, 129:417-431.

68. D'Amico S, Collins T, Marx JC, Feller G, Gerday C: Psychrophilic microorganisms: challenges for life. EMBO Rep 2006, 7:385-389.

69. Demchenko AP, Ruskyn OI, Saburova EA: Kinetics of the lactate dehydrogenase reaction in high-viscosity media. Biochim Biophys Acta 1989, 998:196-203.

70. Siddiqui KS, Bokhari SA, Afzal AJ, Singh S: A novel thermodynamic relationship based on Kramers theory for studying enzyme kinetics under high viscosity. IUBMB Life 2004, 56:403-407.

71. Marx JC, Collins T, D'Amico S, Feller G, Gerday C: Cold-adapted enzymes from marine Antarctic microorganisms. Mar Biotechnol (NY) 2007, 9:293-304

72. Georlette D, Blaise V, Collins T, D'Amico S, Gratia E, Hoyoux A, Marx JC, Sonan G, Feller G, Gerday C: Some like it cold: biocatalysis at low temperatures. FEMS Microbiol Rev 2004, 28:25-42.

73. Rasmussen BF, Stock AM, Ringe D, Petsko GA: Crystalline ribonuclease: A loses function below the dynamical transition at $220 \mathrm{~K}$. Nature 1992, 357:423-424

74. Siglioccolo A, Gerace R, Pascarella S: "Cold spots" in protein cold adaptation: Insights from normalized atomic displacement parameters (B'-factors). Biophys Chem 2010, 153:104-114.

75. Merlino A, Russo Krauss I, Castellano I, De Vendittis E, Rossi B, Conte M, Vergara A, Sica F: Structure and flexibility in cold-adapted iron superoxide dismutases: the case of the enzyme isolated from Pseudoalteromonas haloplanktis. J Struct Biol 2010, 172:343-352.

76. Margesin R, Feller G: Biotechnological applications of psychrophiles. Environ Technol 2010, 31:835-844.

77. Mavromatis K, Feller G, Kokkinidis M, Bouriotis V: Cold adaptation of a psychrophilic chitinase: a mutagenesis study. Protein Eng 2003, 16:497-503.

78. Aurilia V, Rioux-Dubé JF, Marabotti A, Pézolet M, D'Auria S: Structure and dynamics of cold-adapted enzymes as investigated by FT-IR spectroscopy and MD. The case of an esterase from Pseudoalteromonas haloplanktis. J Phys Chem B 2009, 113:7753-7761.

79. D'Amico S, Gerday C, Feller G: Activity stability relationships in extremophilic enzymes. J Biol Chem 2003, 278:7891-7896.

80. Somero GN: Temperature as a selective factor in protein evolution: The adaptational strategy of "compro-mise". J exp Zool 1975, 194:175-188.

81. Feller G, Narinx E, Arpigigny UL, Aittaleb M, Baise E, Genicot S, Gerday C: Enzymes from psychrophilic organisms. FEMS Microbiol Rev 1996, 18:189-202.

82. Feller G, Gerday C: Psychrophilic enzymes: molecular basis of cold adaptation. Cell Mol Life Sci 1997, 53:830-841.

83. Fields PA, Somero GN: Hot spots in cold adaptation: localized increases in conformational flexibility in lactate dehydrogenase A4 orthologs of Antarctic notothenioid fishes. Proc Natl Acad Sci USA 1998, 95:11476-11481.

84. Koutsioulis D, Wang E, Tzanodaskalaki M, Nikiforaki D, Deli A, Feller G, Heikinheimo P, Bouriotis V: Directed evolution on the cold adapted properties of TAB5 alkaline phosphatase. Protein Eng Des Sel 2008, 21:319-327.

85. Bae E, Phillips GN Jr: Structures and analysis of highly homologous psychrophilic, mesophilic, and thermophilic adenylate kinases. J Biol Chem 2004, 27:28202-28208.

86. Aghajari N, Feller G, Gerday C, Haser R: Structures of the psychrophilic Alteromonas haloplanctis a-amylase give insights into cold adaptation at a molecular level. Structure 1998, 6:1503-1516.

87. Michaux C, Massant J, Kerff F, Frère JM, Docquier JD, Vandenberghe I, Samyn B, Pierrard A, Feller G, Charlier P, Van Beeumen J, Wouters J: Crystal structure of a cold-adapted class C beta-lactamase. FEBS J 2008, 8:1687-1697.

88. Kim SY, Hwang KY, Kim SH, Sung HC, Han YS, Cho Y: Structural basis for cold adaptation sequence, biochemical properties, and crystal structure of malate dehydrogenase from a psychrophile Aquaspirillium arcticum. $J$ Biol Chem 1999, 274:11761-11767. 
89. Sælensminde $\mathrm{G}$, Halskau $\varnothing \mathrm{Jr}$, Jonassen I: Amino acid contacts in proteins adapted to different temperatures: hydrophobic interactions and surface charges play a key role. Extremophiles 2009, 1:11-20.

90. Russell NJ: Toward a molecular understanding of cold activity of enzymes from psychrophiles. Extremophiles 2000, 4:83-90.

91. Zartler ER, Jenney FE Jr, Terrell M, Eidsness MK, Adams MW, Prestegard JH: Structural basis for thermostability in aporubredoxins from Pyrococcus furiosus and Clostridium pasteurianum. Biochemistry 2001, 40:7279-7290.

92. Feller G: Molecular adaptations to cold in psychrophilic enzymes. Cell Mol Life Sci 2003, 60:648-662.

93. Pedersen HL, Willassen NP, Leiros I: The first structure of a cold-adapted superoxide dismutase (SOD): biochemical and structural characterization of iron SOD from Aliivibrio salmonicida. Acta Crystallogr Sect F Struct Biol Cryst Commun 2009, 2:84-92.

94. Davail S, Feller G, Narinx E, Gerday C: Cold adaptation of proteins. Purification, characterization, and sequence of the heat-labile subtilisin from the antarctic psychrophile Bacillus TA41. J Biol Chem 1994, 26:17448-17453.

95. Feller G, Zekhnini Z, Lamotte-Brasseur J, Gerday C: Enzymes from coldadapted microorganisms. The class $C$ beta-lactamase from the antarctic psychrophile Psychrobacter immobilis A5. Eur J Biochem 1997, 1:186-191.

96. Russell RJ, Gerike U, Danson MJ, Hough DW, Taylor GL: Structural adaptations of the cold-active citrate synthase from an Antarctic bacterium. Structure 1998, 3:351-361.

97. Feller G, D'Amico D, Gerday C: Thermodynamic stability of a cold-active alpha-amylase from the Antarctic bacterium Alteromonas haloplanctis. Biochemistry 1999, 14:4613-4619.

98. Alvarez M, Zeelen JP, Mainfroid V, Rentier-Delrue F, Martial JA, Wyns L, Wierenga RK, Maes D: Triose-phosphate isomerase (TIM) of the psychrophilic bacterium Vibrio marinus kinetic and structural properties. J Biol Chem 1998, 273:2199-206.

99. Cavicchioli R, Charlton T, Ertan H, Omar SM, Siddiqui KS, Williams TJ: Biotechnological uses of enzymes from psychrophiles. Microb Biotechnol 2011, 4:449-460.

100. Fjerbaek L, Christensen KV, Norddahl B: A review of the current state of biodiesel production using enzymatic transesterification. Biotechnol Bioeng 2009, 5:1298-1315.

101. Lee K-T, Foglia TA, Chang KS: Production of alkyl ester as biodiesel from fractionated lard and restaurant grease. J AmOil Chem Soc 2002, 2:191-195.

102. Lee DH, Kim JM, Shin HY, Kang SW, Kim SW: Biodiesel production using a mixture of immobilized Rhizopus oryzae and Candida rugosa lipases. Biotechnol Bioprocess Eng 2006, 6:522-525.

103. Lee JH, Kim SB, Kang SW, Song YS, Park C, Han SO, Kim SW: Biodiesel production by a mixture of Candida rugosa and Rhizopus oryzae lipases using a supercritical carbon dioxide process. Bioresour Technol 2011, 2:2105-2108.

104. Deng L, Xu XB, Haraldsson GG, Tan TW, Wang F: Enzymatic production of alkyl esters through alcoholysis: A critical evaluation of lipases and alcohols. J Am Oil Chem Soc 2005, 5:341-347.

105. Tan TW, Nie KL, Wang F: Production of biodiesel by immobilized Candida sp. lipase at high water content. App/ Biochem Biotechnol 2006, 2:109-116.

106. Kumari V, Shah S, Gupta MN: Preparation of biodiesel by lipasecatalyzed transesterification of high free fatty acid containing oil from Madhuca indica. Energy Fuels 2007, 1:368-372.

107. Shah S, Gupta MN: Lipase catalyzed preparation of biodiesel from Jatropha oil in a solvent-free system. Process Biochem 2007, 3:409-414.

108. Gupta A, Khare SK: Enzymes from solvent-tolerant microbes: Useful biocatalysts for non-aqueous enzymology. Crit Rev Biotechnol 2009, 29:44-54.

109. Doukyua N, Ogino H: Organic solvent-tolerant enzymes. Biochem Eng J 2010, 48:270-282.

110. Klibanov AM: Why are enzymes less active in organic solvents than in water? Trends Biotechnol 1997, 15:97-101.

111. Zhu X, Zhou T, Wu X, Cai Y, Yao D, Xie C, Liu D: Covalent immobilization of enzymes within micro-aqueous organic media. J Mol Catal B: Enzym 2011, 72:145-149.

112. Ru MT, Dordick JS, Reimer JA, Clark DS: Optimizing the salt-induced activation of enzymes in organic solvents: Effects of lyophilization time and water content. Biotechnol Bioeng 1999, 63:233-241.
113. Torres S, Castro GR: Non-aqueous biocatalysis in homogeneous solvent systems. Food Technol Biotechnol 2004, 42:271-277.

114. Gupta MN, Roy I: Enzymes in organic media. Forms, functions and applications. Eur J Biochem 2004, 13:2575-2583.

115. Gupta MN: Enzyme function in organic solvents. Eur J Biochem 1992, 203:25-32.

116. Ogino H, Uchiho T, Yokoo J, Kobayashi R, Ichise R, Ishikawa H: Role of intermolecular disulfide bonds of the organic solvent-stable PST-01 protease in its organic solvent stability. Appl Environ Microbiol 2001, 67:942-947.

117. Ogino H, Uchiho T, Doukyu N, Yasuda M, Ishimi K, Ishikawa H: Effect of exchange amino acid residues of the surface region of the PST-01 protease on its organic solvent-stability. Biochem Biophys Res Commun 2007, 358:1028-1033.

118. Gupta A, Ray S, Kapoor S, Khare SK: Solvent-stable Pseudomonas aeruginosa PseA protease gene: identification, molecular characterization, phylogenetic and bioinformatic analysis to study reasons for solvent stability. J Mol Microbiol Biotechnol 2008, 15:234-243.

119. Karabec M, Łyskowski A, Tauber KC, Steinkellner G, Kroutil W, Grogan G, Gruber K: Structural insights into substrate specificity and solvent tolerance in alcohol dehydrogenase $\mathrm{ADH}-\mathrm{A}^{\prime}$ ' from Rhodococcus ruber DSM 44541. Chem Commun (Camb) 2010, 34:6314-6316.

120. Rich JO, Dordick JS: Imprinting enzymes for use in organic media. In Enzymes in Nonaqueous Media. Edited by: Vulfson J, Halling PJ, Holland HL. Humana Press: Totowa, NJ; 2000:

121. Rich JO, Mozhaev W, Dordick JS, Clark DS, Khmelnitsky YL: Molecular imprinting of enzymes with water-insoluble ligands for nonaqueous biocatalysis. J Am Chem Soc 2002, 124:5254-5255.

122. Khmelnitsky Y: Biotransformations in organic chemistry A textbook, third edition, by Faber K, Springer-Verlag, Berlin; 1997.

123. Berman HM, Westbrook J, Feng Z, Gilliland G, Bhat TN, Weissig H, Shindyalov IN, Bourne PE: The Protein Data Bank. Nucleic Acids Res 2000, 28:235-242.

124. Guex N, Peitsch MC: SWISS-MODEL and the Swiss-PdbViewer: An environment for comparative protein modeling. Electrophoresis 1997, 18:2714-2723.

125. Premkumar L, Greenblatt HM, Bageshwar UK, Savchenko T, Gokhman I, Sussman $J$, Zamir A: Three-dimensional structure of a halotolerant algal carbonic anhydrase predicts halotolerance of a mammalian homolog Proc Natl Acad Sci USA 2005, 21:7493-7498.

126. Evilia C, Ming X, DasSarma S, Hou YM: Aminoacylation of an unusual tRNA (Cys) from an extreme halophile. RNA 2003, 7:794-801.

127. Bohm G, Jaenicke R: A structure-based model for the halophilic adaptation of dihydrofolate reductase from Halobacterium volcanii. Protein Eng 1994, 7:213-220.

128. Poidevin L, MacNeill SA: Biochemical characterisation of LigN, an NAD +-dependent DNA ligase from the halophilic euryarchaeon Haloferax volcanii that displays maximal in vitro activity at high salt concentrations. BMC Mol Biol 2006, 7:44.

129. Bandyopadhyay AK, Krishnamoorthy G, Padhy LC, Sonawat HM: Kinetics of salt-dependent unfolding of [2Fe-2S] ferredoxin of Halobacterium salinarum. Extremophiles 2007, 4:615-625.

130. Britton KL, Stillman TJ, Yip KSP, Forterre P, Engel PC, Rice DW: Insights into the molecular basis of salt tolerance from the study of glutamate dehydrogenase from Halobacterium salinarum. J Biol Chem 1998, 273:9023-9030.

131. Chantawannakul P, Yoshimune K, Shirakihara Y, Shiratori A, Wakayama M, Moriguchi M: Crystallization and preliminary X-ray crystallographic studies of salt-tolerant glutaminase from Micrococcus luteus K-3. Acta Crystallogr D Biol Crystallogr 2003, 3:566-568.

132. Mevarech $M$, Eisenberg $H$, Neumann E: Malate dehydrogenase isolated from extremely halophilic bacteria of the Dead Sea. 1. Purification and molecular characterization. Biochemistry 1977, 17:3781-3785.

133. Bonnete ÂF, Madern D, Zaccaõ ÈG: Stability against denaturation mechanisms in halophilic malate dehydrogenase "adapt" to solvent conditions. J Mol Biol 1994, 244:436-447.

134. Madern D, Pfister C, Zaccai G: Mutation at a single acidic amino acid enhances the halophilic behaviour of malate dehydrogenase from Haloarcula marismortui in physiological salts. Eur J Biochem 1995, 3:1088-1095. 
135. Richard SB, Madern D, Garcin E, Zaccai G: Halophilic adaptation: novel solvent protein interactions observed in the 2.9 and $2.6 \AA$ resolution structures of the wild type and a mutant of malate dehydrogenase from Haloarcula marismortui. Biochemistry 2000, 5:992-1000.

136. Madern D, Zaccai G: Molecular adaptation: the malate dehydrogenase from the extreme halophilic bacterium Salinibacter ruber behaves like a non-halophilic protein. Biochimie 2004, 86:295-303.

137. Tehei M, Zaccai G: Adaptation to extreme environments: macromolecular dynamics in complex systems. Biochim Biophys Acta 2005, 3:404-410.

138. Manikandan K, Bhardwaj A, Gupta N, Lokanath NK, Ghosh A, Reddy VS, Ramakumar S: Crystal structures of native and xylosaccharide-bound alkali thermostable xylanase from an alkalophilic Bacillus sp. NG-27: structural insights into alkalophilicity and implications for adaptation to polyextreme conditions. Protein Sci 2006, 8:1951-1960.

139. Davlieva M, Shamoo Y: Structure and biochemical characterization of an adenylate kinase originating from the psychrophilic organism Marinibacillus marinus. Acta Crystallogr Sect F Struct Biol Cryst Commun 2009, 8:751-756.

140. Asgeirsson B, Hauksson JB, Gunnarsson GH: Dissociation and unfolding of cold-active alkaline phosphatase from atlantic cod in the presence of guanidinium chloride. Eur J Biochem 2000, 21:6403-6412.

141. Tsigos I, Mavromatis K, Tzanodaskalaki M, Pozidis C, Kokkinidis M, Bouriotis $V$ : Engineering the properties of a cold active enzyme through rational redesign of the active site. Eur J Biochem 2001, 268:5074-5080.

142. Gudjónsdóttir K, Asgeirsson B: Effects of replacing active site residues in a cold-active alkaline phosphatase with those found in its mesophilic counterpart from Escherichia coli. FEBS J 2008, 1:117-127.

143. Bauvois C, Jacquamet $L$, Huston AL, Borel F, Feller G, Ferrer JL: Crystal structure of the cold-active aminopeptidase from Colwellia psychrerythraea, a close structural homologue of the human bifunctional leukotriene $\mathrm{A}_{4}$ hydrolase. J Biol Chem 2008, 34:23315-23325.

144. Huston AL, Haeggström JZ, Feller G: Cold adaptation of enzymes: structural, kinetic and microcalorimetric characterizations of an aminopeptidase from the Arctic psychrophile Colwellia psychrerythraea and of human leukotriene A(4) hydrolase. Biochim Biophys Acta 2008, 11:1865-1872

145. D'Amico S, Gerday C, Feller G: Structural determinants of cold adaptation and stability in a large protein. J Biol Chem 2001, 276:25791-25796.

146. Siddiqui KS, Poljak A, Guilhaus M, Feller G, D'Amico S, Gerday C, Cavicchioli R: Role of disulfide bridges in the activity and stability of a cold-active alpha-amylase. J Bacteriol 2005, 17:6206-6212.

147. Papaleo E, Pasi M, Tiberti M, De Gioia L: Molecular dynamics of mesophilic-like mutants of a cold-adapted enzyme: insights into distal effects induced by the mutations. PLoS One 2011, 9:e24214.

148. Birolo L, Tutino ML, Fontanella B, Gerday C, Mainolfi K, Pascarella S, Sannia G, Vinci F, Marino G: Aspartate aminotransferase from the Antarctic bacterium Pseudoalteromonas haloplanktis TAC 125. Cloning, expression, properties, and molecular modelling. Eur J Biochem 2000, 9:2790-2802

149. Skálová T, Dohnálek J, Spiwok V, Lipovová P, Vondrácková E, Petroková H, Dusková J, Strnad H, Králová B, Hasek J: Cold-active beta-galactosidase from Arthrobacter sp. C2-2 forms compact $660 \mathrm{kDa}$ hexamers: crystal structure at $1.9 \AA$ resolution. J Mol Biol 2005, 2:282-294.

150. Lorentzen MS, Moe E, Jouve HM, Willassen NP: Cold adapted features of Vibrio salmonicida catalase: characterisation and comparison to the mesophilic counterpart from Proteus mirabilis. Extremophiles 2006, 5:427-440.

151. Riise EK, Lorentzen MS, Helland R, Smalås AO, Leiros HK, Willassen NP: The first structure of a cold-active catalase from Vibrio salmonicida at $1.96 \AA$ reveals structural aspects of cold adaptation. Acta Crystallogr D Biol Crystallogr 2007, 2:135-148.

152. Lonhienne T, Zoidakis J, Vorgias CE, Feller G, Gerday C, Bouriotis V: Modular structure, local flexibility and cold-activity of a novel chitobiase from a psychrophilic Antarctic bacterium. J Mol Biol 2001, 310:291-297.

153. Russell RJ, Gerike U, Danson MJ, Hough DW, Taylor GL: Structural adaptations of the cold-active citrate synthase from an Antarctic bacterium. Structure 1998, 6:351-361.

154. Gerike U, Danson MJ, Hough DW: Cold-active citrate synthase: mutagenesis of active-site residues. Protein Eng 2001, 14:655-661.

155. Bell GS, Russell RJM, Connaris H, Hough DW, Danson MJ, Taylor GL: Stepwise adaptations of citrate synthase to survival at life's extremes from psychrophile to hyperthermophile. Eur J Biochem 2002, 269:6250-6260.

156. Kumar S, Nussinov R: Different roles of electrostatics in heat and in cold: Adaptation by citrate synthase. Chem Bio Chem 2004, 5:280-290.

157. Jung SK, Jeong DG, Lee MS, Lee JK, Kim HK, Ryu SE, Park BC, Kim JH, Kim SJ: Structural basis for the cold adaptation of psychrophilic M37 lipase from Photobacterium lipolyticum. Proteins 2008, 1:476-484.

158. Simpson PJ, Codd R: Cold adaptation of the mononuclear molybdoenzyme periplasmic nitrate reductase from the Antarctic bacterium Shewanella gelidimarina. Biochem Biophys Res Commun 2011, 4:783-788.

159. Carginale V, Trinchella F, Capasso C, Scudiero R, Parisi E: Gene amplification and cold adaptation of pepsin in Antarctic fish. A possible strategy for food digestion at low temperature. Gene 2004, 2:195-205.

160. Miyazaki K, Wintrode PL, Grayling RA, Rubingh DN, Arnold FH: Directed evolution study of temperature adaptation in a psychrophilic enzyme. J Mol Biol 2000, 297:1015-1026.

161. Aghajari N, Van Petegem F, Villeret V, Chessa JP, Gerday C, Haser R, Van Beeumen J: Crystal structures of a psychrophilic metalloprotease reveal new insights into catalysis by cold adapted proteases. Proteins 2003, 50:636-647.

162. Xie BB, Bian F, Chen XL, He HL, Guo J, Gao X, Zeng YX, Chen B, Zhou BC, Zhang $Y Z$ : Cold adaptation of zinc metalloproteases in the thermolysin family from deep sea and arctic sea ice bacteria revealed by catalytic and structural properties and molecular dynamics: new insights into relationship between conformational flexibility and hydrogen bonding. $J$ Biol Chem 2009, 14:9257-9269.

163. Zhong CQ, Song S, Fang N, Liang X, Zhu H, Tang XF, Tang B: Improvement of low-temperature caseinolytic activity of a thermophilic subtilase by directed evolution and site-directed mutagenesis. Biotechnol Bioeng 2009, 5:862-870.

164. Sigurdardóttir AG, Arnórsdóttir J, Thorbjarnardóttir SH, Eggertsson G, Suhre K, Kristjánsson MM: Characteristics of mutants designed to incorporate a new ion pair into the structure of a cold adapted subtilisin-like serine proteinase. Biochim Biophys Acta 2009, 3:512-518.

165. Almog O, González A, Godin N, de Leeuw M, Mekel MJ, Klein D, Braun S, Shoham G, Walter RL: The crystal structures of the psychrophilic subtilisin S41 and the mesophilic subtilisin Sph reveal the same calcium-loaded state. Proteins 2009, 2:489-496.

166. Karan R, Khare SK: Stability of haloalkaliphilic Geomicrobium sp. protease modulated by salt. Biochemistry (Mosc) 2011, 76:686-693.

167. Karan R, Singh RK, Kapoor S, Khare SK: Gene identification and molecular characterization of solvent stable protease from a moderately haloalkaliphilic bacterium, Geomicrobium sp. EMB2. J Microbiol Biotechnol 2011, 2:129-135.

168. Ohtani N, Haruki M, Morikawa M, Kanaya S: Heat labile ribonuclease HI from a psychrotrophic bacterium: gene cloning, characterization and site-directed mutagenesis. Protein Eng 2001, 12:975-982.

169. Narinx E, Baise E, Gerday C: Subtilisin from psychrophilic Antarctic bacteria: characterization and site-directed mutagenesis of residues possibly involved in the adaptation to cold. Protein Eng 1997, 10:1271-1279.

170. Matsumoto M, Yokouchi $H$, Suzuki N, Ohata H, Matsunaga T: Saccharification of marine microalgae using marine bacteria for ethanol production. Appl Biochem Biotechnol 2003, 108:247-254.

171. Fukushima T, Mizuki T, Echigo A, Inoue A, Usami R: Organic solvent tolerance of halophilic a-amylase from a Haloarchaeon, Haloarcula sp. strain S-1. Extremophiles 2005, 9:85-89.

172. Chakraborty S, Khopade A, Kokare C, Mahadik K, Chopade B: Isolation and characterization of novel a-amylase from marine Streptomyces sp. D1. J Mol Catalysis B Enzymatic 2009, 58:17-23.

173. Kosjek B, Stampfer W, Pogorevc M, Goessler W, Faber K, Kroutil W: Purification and characterization of a chemotolerant alcohol dehydrogenase applicable to coupled redox reactions. Biotechnol Bioeng 2004, 86:55-62.

174. Kobori H, Sullivan CW, Shizuya H: Heat-labile alkaline phosphatase from antarctic bacteria: rapid 5 ' end-labeling of nucleic acids. Proc Natl Acad Sci USA 1984, 81:6691-6695.

175. Hoyoux A, Jennes I, Dubois P, Genicot S, Dubail F, François JM, Baise E, Feller G, Gerday C: Cold-adapted beta-galactosidase from the Antarctic 
psychrophile Pseudoalteromonas haloplanktis. Appl Environ Microbiol 2001, 67:1529-1535.

176. Maugard T, Gaunt D, Legoy MD, Besson T: Microwave-assisted synthesis of galacto-oligosaccharides from lactose with immobilized betagalactosidase from Kluyveromyces lactis. Biotechnol Lett 2003, 25:623-629.

177. Hildebrandt P, Wanarska M, Kur J: A new cold-adapted $\beta$-D-galactosidase from the Antarctic Arthrobacter sp. 32c- gene cloning, overexpression, purification and properties. BMC Microbiology 2009, 9:151.

178. Bridiau N, Issaoui N, Maugard T: The effects of organic solvents on the efficiency and regioselectivity of $\mathrm{N}$-acetyl-lactosamine synthesis, using the $\beta$-galactosidase from Bacillus circulans in hydro-organic media. Biotechnol Prog 2010, 26:1278-1289.

179. Hatori Y, Sato M, Orishimo K, Yatsunami R, Endo K, Fukui T, Nakamura S: Characterization of recombinant family 18 chitinase from extremely halophilic archaeon Halobacterium salinarum strain NRC-1. Chitin Chitosan Res 2006, 12:201.

180. Essghaier B, Hedi A, Beji M, Jijakli H, Boudabous A, Sadfi-Zouaoui N: Characterization of a novel chitinase from a moderately halophilic bacterium, Virgibacillus marismortui strain M3-23. Annal Microbiol 2011, DOI: 10.1007/s13213-011-0324-4.

181. Doukyu N, Aono R: Purification of extracellular cholesterol oxidase with high activity in the presence of organic solvents from Pseudomonas sp ST-200. Appl Environ Microbiol 1998, 64:1929-1932.

182. Yoshimune K, Shirakihara Y, Wakayama M, Yumoto I: Crystal structure of salt-tolerant glutaminase from Micrococcus luteus $\mathrm{K}-3$ in the presence and absence of its product L-glutamate and its activator Tris. FEBS J 2010, 3:738-748.

183. Hotta Y, Ezaki S, Atomi H, Imanaka T: Extremely stable and versatile carboxyl esterase from a hyperthermophilic archaeon. Appl Environ Microbiol 2002, 68:3925-3931.

184. Khudary RA, Venkatachalam R, Katzer M, Elleuche S, Antranikian G: A coldadapted esterase of a novel marine isolate, Pseudoalteromonas arctica: gene cloning, enzyme purification and characterization. Extremophiles 2010, 14:273-285.

185. Kirk O, Christensen MW: Lipases from Candida antarctica: Unique biocatalysts from a unique origin. Org Process Res Dev 2002, 6:446-451.

186. Giudice AL, Michaud L, de Pascale D, Domenico MD, di Prisco G, Fani R, Bruni V: Lipolytic activity of Antarctic cold adapted marine bacteria. J App/ Microbiol 2006, 101:1039-1048.

187. Joseph B, Ramteke PW, Kumar PA: Studies on the enhanced production of extracellular lipase by Staphylococcus epidermidis. I Gen Appl Microbiol 2006, 52:315-320.

188. Amoozegar MA, Salehghamari E, Khajeh K, Kabiri M, Naddaf S: Production of an extracellular thermohalophilic lipase from a moderately halophilic bacterium, Salinivibrio sp. strain SA-2. J Basic Microbiol 2008, 48:160-167.

189. Gaur R, Gupta A, Khare SK: Purification and characterization of lipase from solvent tolerant Pseudomonas aeruginosa PseA. Process Biochem 2008, 43:1040-1046.

190. Pérez D, Martín S, Fernández-Lorente G, Filice M, Guisán JM, Ventosa A, García MT, Mellado E: A novel halophilic lipase, LipBL, showing high efficiency in the production of eicosapentaenoic acid (EPA). PLOS ONE 2011, 6:e23325.

191. Kamekura M, Hamakawa T, Onishi H: Application of halophilic nuclease $H$ of Micrococcus varians subsp. halophilus to commercial production of flavoring agent 5'-GMP. Appl Environ Microbiol 1982, 44:994-995.

192. Truong LV, Tuyen H, Helmke E, Binh LT, Schweder T: Cloning of two pectate lyase genes from the marine Antarctic bacterium Pseudoalteromonas haloplanktis strain ANT/505 and characterization of the enzymes. Extremophiles 2001, 5:35-44.

193. Ryu K, Kim J, Dordick JS: Catalytic properties and potential of an extracellular protease from an extreme halophile. Enzym Microb Technol 1994, 16:266-275.

194. Kim J, Dordick JS: Unusual salt and solvent dependence of a protease from an extreme halophile. Biotechnol Bioeng 1997, 55:471-479.

195. Bobe IM, Abdelmoez W, Ogino H, Yasuda M, Ishimi K, Ishikawa H: Kinetics and mechanism of a reaction catalyzed by PST-01 protease from Pseudomonas aeruginosa PST-01. Biotechnol Bioeng 2004, 86:365-373.

196. Tsuchiyama S, Doukyu N, Yasuda M, Ishimi K, Ogino H: Peptide synthesis of aspartame precursor using organic solvent-stable PST-01 protease in monophasic aqueous organic solvent systems. Biotechnol Prog 2007, 23:820-823.
197. Gupta A, Roy I, Khare SK, Gupta MN: Purification and characterization of a solvent stable protease from Pseudomonas aeruginosa PseA. J Chrom A 2005, 1069:155-161.

198. Pawar R, Zambare V, Barve S, Paratkar G: Application of protease isolated from Bacillus sp. in enzymatic cleansing of contact lenses. Biotechnol 2009, 8:276-280.

199. Ruiz DM, lannuci NB, Cascone O, De Castro RE: Peptide synthesis catalysed by a haloalkaliphilic serine protease from the archaeon Natrialba magadii (Nep). Lett Appl Microbiol 2010, 51:691-696.

200. Akolkar AV, Durai D, Desai AJ: Halobacterium sp. SP1 (1) as a starter culture for accelerating fish sauce fermentation. J Appl Microbiol 2010, 109:44-53.

201. Karan R, Khare SK: Purification and characterization of a solvent stable protease from Geomicrobium sp EMB2. Environ Technol 2010, 10:1061-1072.

202. Karan R, Singh SP, Kapoor S, Khare SK: A novel organic solvent tolerant protease from a newly isolated Geomicrobium sp. EMB2 (MTCC 10310): production optimization by response surface methodology. N Biotechnol 2011, 2:136-145.

203. Collins T, Hoyoux A, Dutron A, Georis J, Genot B, Dauvrin T, Arnaut F, Gerday C, Feller G: Use of glycoside hydrolase family 8 xylanases in baking. J Cereal Sci 2006, 43:79-84.

204. Dornez E, Verjans P, Arnaut F, Delcour JA, Courtin CM: Use of psychrophilic xylanases provides insight into the xylanase functionality in bread making. J Agric Food Chem 2011, 17:9553-9562.

205. Wang K, Li G, Yu SQ, Zhang CT, Liu YH: A novel metagenome-derived beta-galactosidase: gene cloning, overexpression, purification and characterization. Appl Microbiol Biotechnol 2010, 88:155-165.

206. Prakash P, Jayalakshmi SK, Prakash B, Rubul M, Sreeramulu K: Production of alkaliphilic, halotolerent, thermostable cellulase free xylanase by Bacillus halodurans PPKS-2 using agro waste: single step purification and characterization. World J Microbiol Biotechnol 2011, DOI: 10.1007/s11274011-0807-2.

doi:10.1186/2046-9063-8-4

Cite this article as: Karan et al: Function and biotechnology of

extremophilic enzymes in low water activity. Aquatic Biosystems 2012 8:4.

\section{Submit your next manuscript to BioMed Central and take full advantage of:}

- Convenient online submission

- Thorough peer review

- No space constraints or color figure charges

- Immediate publication on acceptance

- Inclusion in PubMed, CAS, Scopus and Google Scholar

- Research which is freely available for redistribution

Submit your manuscript at www.biomedcentral.com/submit
C Biomed Central 